\title{
Investigating the IT Resources Key Factors in the Iraqi Higher Education Institutions: A Pilot Study
}

\author{
Menyiasat Faktor Utama Sumber IT dalam Institusi Pendidikan Tinggi di Iraq: \\ Satu Kajian Rintis
}

\author{
A. Fahad ${ }^{1}$, A. Meri², A. Altaher ${ }^{3}$, MA Dauwed ${ }^{2}$, N. Hashim² ${ }^{2}$ Sh. Omar ${ }^{4}$ \\ ${ }^{I}$ Faculty of Information Technology, Imam Jafar Al-Sadiq's University, Iraq; \\ ${ }^{2}$ Faculty of Information Science and Technology, Universiti Kebangsaan Malaysia; ahmedmeri@hotmail.com \\ ${ }^{3}$ School of Rehabilitation, Faculty of Health Siences, Universiti Kebangsaan Malaysia \\ ${ }^{4}$ Faculty of Education, Universiti Kebangsaan Malaysia
}

\begin{abstract}
Integrating the new technologies to improve the current educational systems makes it compulsory to the higher education institutions to get use of the current IT resources in order to be able to transform the traditional education ways into the e-learning sytems. In Iraq, there are some antecedents facing the higher education institutions regarding the utilization of e-learning systems. In this paper, the researchers proposed a model of a relationship in which a quantitative research design was chosen to verify the proposed factors and construct the relationship among them. The main factors that may affect the IT readiness was declared as three categories: organisation, communication, and technological structure. These three aspects were found to affect the IT capacity and IT capability of the organization that offer the e-learning systems in order to assess the actual use of these systems in the Iraqi higher education institutions. In order to verify that a designed questionnaire, that is reliable and free of errors, two steps of verifications has been followed up. Firstly, a validation phase in which, the questionnaire checked by a panel of experts in the field of e-learning, the comments received was followed up before proceeding to the second phase. Secondly, a pilot study was conducted to check the reliability of the instrument. The collected data has been analysed using the Cronbach's Alpha coefficient reliability test in SPSS 24 software package. The results showed that all factors are reliable as they gained a value of 0.7 and above in the test.
\end{abstract}

Keywords: E-learning, IT-readiness, higher education institutions, pilot study.

\section{Abstrak}

Mengintegrasikan teknologi baharu untuk memperbaiki sistem pendidikan semasa menjadi satu kewajiban kepada institusi pengajian tinggi untuk menggunakan sumber IT semasa dalam memastikan transformasi pendidikan konvensional ke sistem e-pembelajaran. Di Iraq, terdapat beberapa isu asas yang dihadapi oleh institusi pengajian tinggi berkaitan dengan penggunaan sistem epembelajaran. Artikel ini mencadangkan model hubungan yang mana reka bentuk kajian kuantitatif telah dipilih untuk mengesahkan faktor yang dicadangkan dan membina hubungan antara faktor berkenaan. Faktor utama yang bakal memberi kesan kepada kesediaan IT boleh dibahagikan kepada 
tiga kategori: organisasi, komunikasi dan struktur teknologi. Tiga faktor ini didapati menjejaskan kapasiti dan keupayaan IT di organisasi yang menawarkan sistem e-pembelajaran dalam memastikan capaian kepada penggunaan sebenar sistem berkenaan di institusi pengajian tinggi di Iraq. Bagi mengesahkannya, borang soal selidik disediakan, yang dipercayai dan bebas errata, dua langkah pengesahan telah dilaksanakan. Pertama, fasa pengesahan di mana borang soal selidik ini diperiksa oleh panel pakar dalam bidang e-pembelajaran, komen yang diterima dibawa sebelum maju ke fasa kedua. Kedua, satu kajian rintis telah dilaksanakan untuk memeriksa kebolehpercayaan instrumen. Data yang dikumpul dianalisis menggunakan ujian kebolehpercayaan Cronbach' Alpha menggunakan pakej perisian SPSS 24. Keputusan menunjukkan bahawa semua faktor boleh dipercayai dengan nilai 0.7 dan ke atas dalam ujian yang dijalankan.

Kata kunci: E-pembelajaran, kesediaan IT, institusi pengajian tinggi, kajian rintis.

\section{INTRODUCTION}

Information Technology (IT) resources relates to the usage of various software services in order to fulfil a particular objective. This includes solutions such as computer software to process information assigned to education that can be found into e-learning, blended learning, mobile learning, distance education and online learning. The effectiveness of these resources in enhancing learning has been reflected into the learners who used e-learning in their daily practices (Kozma, 2008). E-learning refers to the learning practices by numerous sets of services available online via the Internet. These sets are capable to formulate and customize in order to handle a new model according to the adaptation of some other learning technologies or even through utilizing the IT resources like computer, communication, networks, and mobile technology for an improved learning (Abdullah \& Hassan, 2016; Meri, Hasan, \& Safie, in press). This kinds of process might help supply and try to make education and information available to whoever wants it (Fahad et. al., 2016; Tinio, 2003). With e-learning, the focus is no longer on the teacher, but both the lecturer and student especially, who take advantage of technology to various resources of knowledge made available by the existing technology.

The adaptation of IT services and tools has become one of the key standards for creating the needed objects for modern society. A good attention is given toward including key factors for developing an appropriate IT model in various developing countries, which in turn consists of understanding along with mastering the important approaches and experience in order to be adapted as a primary component of the core of education, alongside reading, writing and numeracy (Meri, Hasan, \& Safie, 2017, in press; UNESCO, 2011b).

UNESCO (2011a) reported the existing utilization of IT as well as ICT resources in the educational process in various Iraqi organizations that announced that the increasing status of the teaching and learning quality is related to the enhancement of IT literacy as well as skills in the Iraqi institutions. The UNESCO report demands the advancement and distribution of various e-learning resources together with a trained teacher to be able to guide students about make use of e-learning tools. 
On the other hand, Alhadithi, Idrus \& Elameer (2011) have identified the real obstacle in the Iraqi Public Higher Education (IPHE) as "how to react to such changes in the education environment with strategic modernization by examining new concepts and models". They pointed out the current weakness faced by these institutions to apply IT resources and its impact on the learning quality. They recommended a number of ways to get rid of these lacks on the IT use in IPHE; for example, one of these methods is to utilize e-education system to be able to support in dealing with all the IPHE issues. However, the success within utilizing e-education resources and services requires various procedures to be deemed in terms of "planning, designing, evaluating, and implementing online learning environments where learning is actively fostered and supported" (Bates, 2005; A. Fahad, Hassan, \& Salman, 2013). Therefore, infrastructure of using IT should have the capability to support the different learning actions in the e-education system which the majority of universities are depends on.

Several postgraduate and undergraduate study programmers within the learning system have been insufficient because of the lacking of utilizing IT tools to carry out the class requirements for teaching a certain subject in addition to the unstable circumstances associated with security as well as lack of resources (Alhadithi et al., 2011; Kadhum \& Hasan, 2017). A good example is the inadequate number of qualified staff members in universities resulting in which students do not be able to capable obtaining the useful instructions and directions from experienced lecturers (Bates, 2005; A. N. Fahad, Hassan, Sulaiman, \& Rahman, 2015).

Adopting and utilizing IT infrastructure is very important success element for any modern educational institution. For instance, appropriate identification regarding IT factors which affect implementation are really critical for every university to realize its objectives. Besides that, the e-learning implementation in Iraqi universities needs a set of different organisation structure, IT mechanisms, communication structure and technological structure. Hence, this study discusses these issues by showing these three elements in order to assess the existing IT state to utilize e-learning systems in the Iraqi universities in terms of IT capacity and IT capability.

\section{MATERIAL AND METHOD}

A descriptive, survey research design was chosen to investigate the main factors related to the organization, technology, communication, IT readiness and Actual use of IT in the Iraqi higher education institutions. A questionnaire technique was used for data collection in order to determine university instructors' views about the validity of the research variables. The main reason for choosing questionnaire back to its feasibility in simplifying the analysis of the data more 'scientifically' and objectively than other forms of research. In addition, it can also help researcher to compare and contrast other research and may be used to measure change positivists believe for examining existing hypotheses (Wright, 2005). 


\section{Questionnaire Design}

The designed instrument tool was based on closed ended questions, in which the respondents have to give an exact answer for each question/item. All the items were adapted from previous studies that based on the contents of each factor. Table 1 shows the operationalization of the factors and items. Five likert scale (strongly disagree, disagree, not sure, agree, strongly agree) used in this study to determine the level of agreement among the respondents. Five likert scale is one of the widely used scale for providing a clear view about one's proposition in certain aspect. Before starting the questionnaire, a brief description about the research study and its objectives along with a confidentiality rules have been provided. The questionnaire written in English and then translated into Arabic, which is the official language in Iraq. The questionnaire consists of three identical sections (demographic background, instructions and assessment factors).

\section{Validation}

The questionnaire validity assessed by taken some steps before the final distribution in order to ensure that all questions/items are correct and free of errors. These steps involves sending the questionnaire to three experts in the field. Those experts are instructors in the Iraqi universities that have an experience using e-learning systems. The questionnaire evaluated for language, clarity, contradiction or duplication. Before the distribution, some recommendations and comments followed up by applying appropriate modifications.

\section{PILOT STUDY}

A number of researchers recommended conducting pilot studies (Goodman, Meltzer, \& Bailey, 1998; Smith \& Studd, 1992). The aim of the pilot study is to test the research instrument. According to Cohen, Manion \& Morrison (2013), all gathered data need to be piloted in order to verify that all questions and even instructions are very clear. This procedure allows the researchers to eliminate any items which do not yield useful data. Therefore, the function of the pilot study is to make sure that the chosen format for the study is appropriate before proceeding to apply the main tool.

Thus, the questionnaire was distributed among instructors of the faculty of computer science in two public universities in Iraq. A total of 39 responses has been received, and this considered appropriate for a pilot study as suggested by (Johanson \& Brooks, 2010), who declared that 30 representative participants from the population of interest is a reasonable minimum recommendation for pilot study where the purpose is preliminary survey. The participants' demographic background items are (1) gender (27 males and 12 females), (2) age group (22 of them 18-25 years old, 12 aged 26-35 years old, while 5 are more than 35 years old), and (3) experience using e-learning systems ( 5 of them never used e-learning, 12 have an experience of 1-2 years, while 22 of them have experiences more than 2 years). 


\section{RESULTS}

The most commonly used test in reliability measurement of any pilot study questionnaire is Cronbach's Alpha (Cronbach, 1946; Sekaran \& Bougie, 2010). According to George \& Mallery (2003), Cronbach's Alpha test possesses values within the range of 0 to 1; a higher level of range indicates greater value of reliability. Values of 0.9 and above are excellent, 0.8 and above are good, 0.7 and above are acceptable, 0.6 and above are questionable, and less than 0.6 are poor.

The data collected from the pilot study have been analysed using Statistical Package for the Social Sciences 24 to identify the values of each factor in Cronbach's Alpha.

Based on the pilot study, the test result showed that all items are reliable since it resulted in a value of about 0.7 and above cronbach's alpha reliability test. Table 1 shows Cronbach's Alpha and number of items for each factor.

Table 1: Operationalization of the factors/items and Cronbach's Alpha.

\begin{tabular}{lclc}
\hline \multicolumn{1}{c}{ Factor } & Items & \multicolumn{1}{c}{ References } & Cronbach's Alpha \\
\hline Internet Network & 4 & (Tallon, 2008) & .701 \\
Software Quality & 6 & (Lewis, 1995) & .720 \\
Hardware Availability & 5 & (Chanyagorn \& Kungwannarongkun, 2011) & .743 \\
Human Resources & 6 & (Mutula \& Van Brakel, 2006) & .761 \\
Policy & 5 & (Mutula \& Van Brakel, 2006; Nichols, 2008) & .707 \\
Connectivity & 6 & (Capricho, Obenque, \& Musni, 2011) & .701 \\
Shareability & 6 & (Usoro, Sharratt, Tsui, \& Shekhar, 2007) & .698 \\
IT Capacity & 5 & $\begin{array}{l}\text { (Archibugi \& Coco, 2005; Aydin \& Tasci, 2005; } \\
\text { (Archibugi \& Kungwannarongkun, 2011) }\end{array}$ & .781 \\
IT Capability & 7 & $\begin{array}{l}\text { Chanyagorn \& Kungwannarongkun, 2011) } \\
\text { (Khan, Bhatti, \& Ahmad Khan, 2011; Venkatesh }\end{array}$ & .805 \\
Actual Use of IT & 5 & \& Davis, 1996) & .734 \\
\hline
\end{tabular}

\section{DISCUSSION}

This study was proposed to examine the influencing factors that affect the e-learning systems in the Iraqi higher education institutions. This study was prompted by a real need to examine the requirements, challenges, and gaps facing the full utilization of e-learning systems in Iraqi universities. A questionnaire was designed based on previous studies that investigate the proposed factors. A pilot study were conducted to examine each influencing factor and to test the reliability of the questionnaire. This kind of studies were required to verify that all items are reliable and free of errors. Cronbach's Alpha test in the pilot study reveals that all factors have values of 0.7 and above, which are acceptable. The pilot study was conducted using questionnaire that was disseminated to instructors of computer science faculty in two public universities in Iraq. A research paper will follow 
this study to illustrate the results of the data analysis of the survey. Future research will then test the hypotheses and validate the final model.

\section{ACKNOWLEDGEMENTS}

We gratefully acknowledge all the participants in this study for giving us a portion of their time.

\section{REFERENCES}

Abdullah, I., \& Hassan, Z. (2016). Cloud Technology Adoption Model: A Case of Iraqi SMES. Journal of Engineering and Applied Sciences, 11(3), 505-513.

Ahmed Fahad, Z. H. and Z. S. (2016). Barriers of Adopting E-Learning in Developing Countries. Journal of Engineering and Applied Sciences, 11(12), 2815-2820.

Alhadithi, A., IDRUS, R. M., \& ELAMEER, A. S. (2011). Re-engineering Iraqi Higher Education with the E-Education Solutions. Recent Researches in Education, 37-42.

Archibugi, D., \& Coco, A. (2005). Measuring technological capabilities at the country level: A survey and a menu for choice. Research Policy, 34(2), 175-194.

Aydin, C. H., \& Tasci, D. (2005). Measuring readiness for e-learning: reflections from an emerging country. Journal of Educational Technology \& Society, 8(4).

Bates, A. W. T. (2005). Technology, e-learning and distance education. Routledge.

Capricho, N. C., Obenque, M. M., \& Musni, F. M. F. (2011). The Internet Connection as Academic-Services Provider: An Assessment of Technology's Relevance to the Curriculum by the Student Internet Users. UIC Research Journal, 17(2), 1.

Chanyagorn, P., \& Kungwannarongkun, B. (2011). ICT readiness assessment model for public and private organizations in developing country. International Journal of Information and Education Technology, 1(2), 99.

Cohen, L., Manion, L., \& Morrison, K. (2013). Research methods in education. Psychology Press.

Cronbach, L. J. (1946). Response sets and test validity. Educational and Psychological Measurement, 6(4), 475-494.

Fahad, A., Hassan, Z., \& Salman, Z. (2013). A study towards using E-learning based information technology resources for the development of students thinking skills in higher education. In Intelligent Systems Modelling \& Simulation (ISMS), 2013 4th International Conference on (pp. 331-334). IEEE.

Fahad, A. N., Hassan, Z., Sulaiman, R. B., \& Rahman, Z. (2015). Usability Evaluation of E-Learning Systems in the Iraqi Higher Education Institutions. International Journal of Internet of Things, 4(1A), 30-34.

George, D., \& Mallery, M. (2003). Using SPSS for Windows step by step: a simple guide and reference.

Goodman, R., Meltzer, H., \& Bailey, V. (1998). The Strengths and Difficulties Questionnaire: A pilot study on the validity of the self-report version. European Child \& Adolescent Psychiatry, 7(3), 125-130.

Johanson, G. A., \& Brooks, G. P. (2010). Initial scale development: sample size for pilot studies. Educational and Psychological Measurement, 70(3), 394-400.

Kadhum, A. M., \& Hasan, M. K. (2017). Assessing the determinants of cloud computing services for utilizing health information systems: A case study. International Journal on Advanced Science, Engineering and Information Technology, 7(2), 503-510. https://doi.org/10.18517/ijaseit.7.2.1814

Khan, S. A., Bhatti, R., \& Ahmad Khan, A. (2011). Use of ICT by Students: A Survey of Faculty of Education at IUB.

Kozma, R. B. (2008). Comparative analysis of policies for ICT in education. In International handbook of information technology in primary and secondary education (pp. 1083-1096). Springer.

Lewis, J. R. (1995). IBM computer usability satisfaction questionnaires: psychometric evaluation and instructions for use. International Journal of Human - Computer Interaction, 7(1), 57-78.

Meri, A., Hasan, M. K., \& Safie, N. (2017). Success factors affecting the healthcare professionals to utilize cloud computing services. Asia-Pacific Journal of Information Technology and Multimedia, 6(2), 31-42.

Meri, A., Hasan, M. K., \& Safie, N. (in press). The Impact of Organizational Structure and System Settings on the Healthcare Individuals' Perception to Utilize Cloud Services: A Theoretical Literature Survey. Journal of Engineering and Applied Sciences.

Meri, A., Hasan, M. K., \& Safie, N. (in press). Towards Utilizing Cloud Health Information Systems: A Proposed Model. Journal of Engineering and Applied Sciences.

Mutula, S. M., \& Van Brakel, P. (2006). An evaluation of e-readiness assessment tools with respect to information access: Towards an integrated information rich tool. International Journal of Information Management, 26(3), 212-223. 
Nichols, M. (2008). Institutional perspectives: The challenges of e- learning diffusion. British Journal of Educational Technology, 39(4), 598-609.

Sekaran, U., \& Bougie, R. (2010). Theoretical framework In theoretical framework and hypothesis development. Research Methods for Business: A Skill Building Approach. United Kingdom: Wiley.

Smith, R., \& Studd, J. W. W. (1992). A pilot study of the effect upon multiple sclerosis of the menopause, hormone replacement therapy and the menstrual cycle. Journal of the Royal Society of Medicine, 85(10), 612-613.

Tallon, P. P. (2008). Inside the adaptive enterprise: an information technology capabilities perspective on business process agility. Information Technology and Management, 9(1), 21-36. https://doi.org/10.1007/s10799-007-0024-8

Tinio, V. L. (2003). ICT in Education. e-ASEAN Task Force.

UNESCO. (2011a). Information \& Communication Technologies for Education. UNESCO Iraq Computer labs established to help integrate ICT in Education Retrieved 2-June, 2011, from http://www.unesco.org/en/iraqofficeleducation-sector-atthe-unesco-office-foriraq/general-educati.

UNESCO. (2011b). Training Teachers for Sustainable Quality Education in Iraq. UNESCO Iraq Training of university professors in Iraq Retrieved 1-June, 2011, from http://www.unesco.org/en/iraq-officeleducationsector-at-the-unescooffice-for-iraq/higher-education-iniraq/tra.

Usoro, A., Sharratt, M. W., Tsui, E., \& Shekhar, S. (2007). Trust as an antecedent to knowledge sharing in virtual communities of practice. Knowledge Management Research \& Practice, 5(3), 199-212.

Venkatesh, V., \& Davis, F. D. (1996). A model of the antecedents of perceived ease of use: Development and test. Decision Sciences, 27(3), 451-481.

Wright, K. B. (2005). Researching Internet based populations: Advantages and disadvantages of online survey research, online questionnaire authoring software packages, and web survey services. Journal of Computer Mediated Communication, 10(3). https://doi.org/10.1111/j.1083-6101.2005.tb00259.x 